\title{
Czy można rozdzielić prymat nauczania od prymatu jurysdykcji? Perspektywa ekumeniczna
}

\section{Expositio quaestionis}

Kwestia prymatu św. Piotra i jego kontynuacja w posłudze biskupów stanowi zapalny punkt dialogu ekumenicznego ${ }^{1}$. Cieszyć się więc należy, że poszukiwanie odpowiedniej formuły dla realizacji urzędu papieża jest przedmiotem studiów w Kościele katolickim oraz w innych chrześcijańskich Kościołach i wspólnotach ${ }^{2}$. Niejednokrotnie inspiracją dla tych działań jest pragnienie wyrażone przez bł. papieża Jana Pawła II w Encyklice Ut unum sint, aby Duch Święty obdarzył swoim światłem i oświecił pasterzy i teologów z różnych Wspólnot chrześcijańskich, by poszukiwali takich form sprawowania owego urzędu, w których możliwe będzie realizowanie uznawanej przez wszystkich posługi miłości ${ }^{3}$,

I Por. J. Ratzinger, Kościót wspólnota, Lublin 1993, s. 31.

2 Zob. np. Joannes Paulus PP. II, Litt. enc. Ut unum sint de Oecumenico officio, [dalej: Ut unum sint], 25 V 1995, „Acta Apostolicae Sedis”, [dalej: AAS], 1995, vol. 87, s. 921-982. Przykładowe inicjatywy w tym temacie innych Kościołów i wspólnot kościelnych zob. tamże, nr 89, przyp. 148 i przyp. 149.

3 Por. tamże, nr 95. 
tak aby prymat, czyli to „podstawowe dobro” (primarium bonum), zostało przyjęte przez tych, którzy nie są w jedności z Kościołem katolickim ${ }^{4}$.

Słusznie zauważono, że problemem o ekumenicznym znaczeniu nie jest sam fakt istnienia ustanowionego przez Chrystusa urzędu, lecz formy jego urzeczywistnienia ${ }^{5}$. Chodzi więc o znalezienie takiego modelu wykonywania prymatu, który nie odrzucając istotnych elementów tej misji, byłby otwarty na nową sytuację chrześcijaństwa we współczesnym świecie, który potrzebuje świadectwa jedności wyznawców Chrystusa ${ }^{6}$.

Celem niniejszego referatu jest włączenie się w ten nurt szukania ekumenicznych rozwiązań poprzez odpowiedź na pytanie zawarte w jego tytule: Czy można rozdzielić prymat nauczania od prymatu jurysdykcji? Odpowiedź na tę kwestię ma być odpowiedzią katolicką, lecz ujętą z perspektywy ekumenicznej. Oznacza, to, że z jednej strony koniecznie jest zachowanie pełnej ortodoksji, a z drugiej poszukiwaniom musi przyświecać chęć uzyskania akceptacji ze strony innych chrześcijańskich Kościołów czy wspólnot. Z tej racji, że omawiany problem jest szczególnie ważny dla stosunków pomiędzy luteranami a katolikami ${ }^{7}$, właśnie ten nurt chrześcijaństwa znajdzie się w optyce niniejszego wykładu ${ }^{8}$.

Drogą, jaką dokona się poszukiwanie odpowiedzi, będzie metoda św. Tomasza z Akwinu. Najpierw zostaną wysunięte argumenty pozwalające

4 Por. tamże, nr 88.

5 Por. M. Lukoszek, Podstawy reinterpretacji dogmatu o prymacie biskupa Rzymu Soboru Watykańskiego I, „Polonia Sacra”, R. 14, 2010, nr 26-27, s. 183.

6 Por. Ut unum sint, nr 95.

7 Zob. Ewangelia a Kościót, czyli tzw. Raport z Malty, [dalej: Raport z Malty], przeł. I. Drucki, [w:] Wszyscy pod jednym Chrystusem. Ogólnokościelny dialog katolicko-luterański. Część 1: 1965-1981, red. W. Hryniewicz, S. C. Napiórkowski, Lublin 1985 , s. 117-139, tu nr 66. Raport z Malty to dokument luterańsko-katolickiej komisji powołanej przez Papieską Radę do Spraw Popierania Jedności Chrześcijan oraz Światową Federację Luterańską w sprawie dialogu ekumenicznego, podpisany 9 II 1972 w Rzymie i w Genewie.

$8 \mathrm{Na}$ temat tego zagadnienia prymatu w relacji Kościoła katolickiego do prawosławia zob. np. W. Hryniewicz, Prymat papieski w świetle wspótczesnej teologii prawosławnej, „Zeszyty Naukowe Katolickiego Uniwersytetu Lubelskiego", R. 16, 1973, s. 65-80 oraz A. Buchenfeld, Prymat Biskupa Rzymu w perspektywie dialogu katolicko-prawostawnego i katolicko-luterańskiego, „Summarium Societatis Scientiarum Catholicae Universitatis Lublinensis Ioannis Pauli II”, R. 40-41, 1991-1992, nr 20-21, s. 5-18. 
na pozytywną odpowiedź na postawione pytanie badawcze. W drugiej części odczytu zostaną podane kontrargumenty, czyli racje zaprzeczające stanowisku zaprezentowanemu w części poprzedniej. Zarówno pierwsze, jak i drugie uzasadnienie oparte będzie na dokonaniach filozofii, teologii luterańskiej i teologii katolickiej. Prelekcję zakończy jednoznaczna odpowiedź na pytanie zawarte w jego tytule.

\section{Pro}

Przechodząc do dowodzenia możliwości rozdziału prymatu nauczania od prymatu jurysdykcji, wydaje się, iż wolno powiedzieć, że takie rozdzielenie jest możliwe. Dowodzić by miały tego następujące argumenty.

\subsection{Argumentum philosophicum}

$\mathrm{Na}$ początku wypada odwołać się do podstawy filozoficznej takiego potencjalnego rozdzielenia prymatu. Pomocne w tym mogą być rozważania na temat autorytetu J. M. Bocheńskiego. Według tego filozofa każdy autorytet $\mathrm{w}$ swojej istocie jest stosunkiem trójczłonowym między podmiotem autorytetu, przedmiotem autorytetu i dziedziną autoryte$\mathrm{tu}^{9}$. Autor ten stoi na stanowisku, że istnieją tylko dwa rodzaje autorytetu, bowiem: „Każdy autorytet jest autorytetem epistemicznym albo deontycznym" 10 .

Autorytet epistemiczny to autorytet podmiotu, którego wiedza jest większa niż wiedza innych osób, czyli przedmiotów autorytetu. Jest to np. autorytet nauczyciela wobec uczniów. Trzeba dodać, że autorytet ten przysługuje tym, którzy lepiej, głębiej znają dziedzinę autorytetu, czyli np. jakiś określony zakres wiedzy ${ }^{11}$.

Z kolei autorytet deontyczny nie jest autorytetem człowieka, który wie lepiej, ale tego, który ma władzę i to daje mu prawo i możliwość narzucania

9 Por. J. M. Bocheński, Co to jest autorytet?, [w:] Logika i filozofia. Wybór pism, przeł. J. Parys, Warszawa 1993, s. 202n.

ro Tamże, s. 236.

Ir Zob. szerzej tamże, s. 240-253. 
swojej woli przedmiotowi autorytetu ${ }^{12}$. Jest to więc autorytet, jakim cieszy się przełożony, zwierzchnik wobec podwładnych ${ }^{13}$.

Przenosząc te rozważania na zagadnienie prymatu, trzeba zauważyć, że istnieje wyraźne podobieństwo autorytetu deontycznego do autorytetu, jaki charakteryzuje władzę jurysdykcyjną, wykonywaną w ramach prymatu jurysdykcyjnego. Prymat nauczycielski wiąże się z kolei z autorytetem epistemicznym. Źródło tej wiedzy może być naturalne lub nadnaturalne, zaś dziedziną jest Objawienie.

Powyższy argument jest czytelny - filozofia, jak się wydaje, pozwala na rozdzielenie prymatu nauczania od prymatu jurysdykcji.

\subsection{Argumentum theologiae lutheranae}

Z kolei należy podać argumenty z teologii luterańskiej, które choć są przeciwne generalnie prymatowi, a szczególnie prymatowi jurysdykcji, to, jak się wydaje, mogą być użyte jako argument przemawiający za rozdzieleniem prymatu ${ }^{14}$.

Trzeba rozpocząć od Traktatu o władzy i prymacie papieża autorstwa F. Melanchtona ${ }^{15}$. Interesujące, z punktu widzenia tego referatu, są następujące uwagi zaprzeczające wprost jurysdykcji papieża, a w pewnym stopniu akceptujące jego prymat nauczania.

Po pierwsze, Biskup Rzymski nie jest z prawa Bożego postawiony ponad innymi biskupami lub pasterzami. Oznacza to, że nie ma on władzy jurysdykcji ${ }^{16}$. „Zwierzchnictwo papieża nad biskupami jest niemożliwością i nigdy nie było wprowadzone w życie i nie uznają go zbory przeważającej części świata, dostatecznie jest jasne, że nie zostało ono ustanowione" - pisze F. Me-

I2 Zob. powszechnie uznaną definicję władzy: M. Weber, Grundriss der Sozialökonomik, t. 3: Wirtschaft und Gesellschaft, Tübingen 1922, s. 28: „Macht bedeutet jede Chance, innerhalb einer sozialen Beziehung den eignen Willen auch gegen Widerstreben durchzusetzen, gleichviel worauf diese Chance beruht".

r3 Zob. szerzej: J. M. Bocheński, Co to jest autorytet?, dz. cyt., s. 266-277.

${ }^{14}$ Szeroko o luterańskich poglądach na papieski prymat zob. np. E. Bizer, Luther and der Papst, München 1958; H. H. Scott, Luther and the Papacy, Philadelfia 1981.

I5 Por. F. Melanchton, Traktat o wtadzy i prymacie papieża, [w:] Ksiegi wyznaniowe Kościoła luterańskiego, Bielsko-Biała 2003, s. 359-372.

i6 Por. Traktat o wtadzy i prymacie papieża, $\mathrm{nr} 7$. 
lanchton ${ }^{17}$. Autor cytowanego traktatu, używając argumentów z Pisma Świętego i z historii Kościoła, wykazuje, że jurysdykcja papieża nie może istnieć, bo szkodzi Kościołowi.

Po drugie, konsekwencją prymatu jurysdykcji jest zasada zakazująca sądzenia papieża, czyli „prima sedes a nemine iudicatur” ${ }^{18}$. „Papież - pisze współtwórca Reformacji - nie chce poddać się sądowi Kościoła lub kogokolwiek i stawia wyżej swój autorytet ponad sąd soboru i całego Kościoła. To zaś znaczy: czynić się Bogiem i nie uznawać nad sobą sądu Kościoła lub kogokolwiek $^{19 "}$.

Podobne do zaprezentowanego stanowisko zawierają napisane przez M. Lutra Artykuty szmalkaldzkie ${ }^{20}$. W kontekście podziału prymatu można je streścić w następujących punktach:

1. Papież nie jest z prawa Bożego głową całego chrześcijaństwa, lecz jest on jedynie biskupem, który znajduje się w Rzymie ${ }^{21}$.

2. Papiestwo jako władza nad Kościołem jest wymysłem ludzkim, a nie rzeczą nakazaną. W konsekwencji jest ono niepotrzebne i nieużyteczne ${ }^{22}$.

3. Papież mógłby mieć pewną władzę nad Kościołem, gdyby mu ją dobrowolnie przyznano, czyli posiadałby ją jedynie z wolnej ludzkiej woli, a nie na podstawie prawa Bożego ${ }^{23}$.

Współczesna teologia luterańska, choć nie jest niejednorodna w poglądach na temat prymatu ${ }^{24}$, zasadniczo podtrzymuje powyższe przekonania, zawarte w księgach wyznaniowych luteranizmu ${ }^{25}$.

${ }_{17}$ Por. tamże, nr 16.

I8 Por. kan. 1404, Codex Iuris Canonicia auctoritate Ioannis Pauli PP. II promulgatus, AAS, 1983, vol. 75, cz. I, s. 1-318; por. kan. 1058, Codex Canonum Ecclesiarum Orientalium auctoritate Ioannis Pauli PP. II promulgatus, AAS, 1990, vol. 82, s. 1061-1363.

19 Traktat o wtadzy i prymacie papieża, nr 40.

${ }_{20}$ Por. M. Luter, Artykuły szmalkaldzkie, [w:] Księgi wyznaniowe Kościoła luterańskiego, Bielsko-Biała 1999, s. 335-358.

2I Por. Artykuty szmalkaldzkie, cz. II, art. IV, 1.

${ }_{22}$ Por. tamże, cz. II, art. IV, 5.

23 Por. tamże, cz. II, art. IV, 8.

${ }_{24}$ Por. M. Żmudziński, „Ty jesteś Piotr”. Świadomość funkcji prymacjalnej Jana Pawta II, Olsztyn 2003, s. 167; M. Hintz, Urzad Biskupa Rzymu zperspektywy ewangelickiej, [w:] Postannictwo Biskupa Rzymu, red. J. Jezierski, Olsztyn 2002, s. 153.

25 Por. H. Meyer, Primat, [w:] Lexikon der Reformationszeit, red. K. Ganzer, B. Steimer, Freiburg - Basel - Wien 2002, kol. 610-611. 
Podsumowując, trzeba powiedzieć, że stanowisko luterańskie może być sprowadzone do następującego stwierdzenia: prymat nauczania jest do zaakceptowania, natomiast prymat jurysdykcji nie ${ }^{26}$. Rozdzielnie prymatu zostałoby więc prawdopodobnie uznane za akt zmierzający do ekumenicznego zbliżenia luteranizmu i katolicyzmu.

\subsection{Argumentum theologiae catholicae}

Wydaje się, że katolicka teologia dopuszcza podział, a w konsekwencji również jest możliwe rozdzielenie prymatu nauczania od prymatu jurysdykcji.

Można tak sądzić po pierwsze dlatego, że prymat został rozróżniony w zakresie pojęciowym. Sobór Watykański I, na którym Kościół katolicki wyłożył w encyklice Pastor eaternus ${ }^{27}$ naukę o prymacie, głosi, że wszyscy wierni Chrystusa powinni wierzyć, że Biskup Rzymski posiada prymat nad całym światem. Oznacza to, że papież jest nauczycielem wszystkich chrześcijan, ma więc prymat nauczania ${ }^{28}$, oraz - głosi Sobór - że papież ma także pełnię władzy pasterzowania, rządzenia i kierowania Kościołem powszechnym, czyli ma prymat jurysdykcji ${ }^{29}$.

W teologii katolickiej mówi się jednak nie tylko o prymacie nauczania i prymacie jurysdykcji. Na powyższym podziale myśl katolicka nie kończy, uważa się bowiem, że primatus iurisdictionis należy odróżnić jeszcze od innych form władztwa, a mianowicie od primatus inspectionis, primatus directionis czy primatus honoris ${ }^{30}$.

26 Por. A. Buchenfeld, Prymat Biskupa Rzymu w perspektywie..., dz. cyt., s. 11.

27 Sacrosanctum Concilium Oecumenicum Vaticanum I, Sessio IV, 18 VII 1870, Constitutio dogmatica I Pastor aeternus de Ecclesia Christi, [w:] H. Denzinger, A. Schönmetzer, Enchiridion symbolorum, definitionum et declarationum de rebus fidei et morum, [dalej: DS], red. P. Hünermann, Bologna 1995, nr 3050-3075; polska wersja: Dokumenty soborów powszechnych. Tekst łaciński, polski, red. A. Baron, H. Pietras, t. 4, (1511-1879), Kraków 2004, s. 912927. Por. Sobór Florencki, sesja 6, Bulla unii z Grekami, nr 17, [w:] Dokumenty soborów powszechnych. Tekst grecki, łaciński, arabski, ormiański, polski, t. 3, 1414-1445: Konstancja, Bazylea-Ferrara - Florencja-Rzym, oprac. A. Baron, H. Pietras, Kraków 2003, s. 474-475.

28 Por. DS 3065.

29 Por. DS 3053-3059.

3o Por. W. Beinert, Primat. Systematisch-theologisch, [w:] Lexikon der Papste und des Papsttums, Lexikon für Theologie und Kirche. Kompakt, red. B. Steimer, Freiburg - Basel - Wien 2001, kol. 626; zob. DS 3055. 
Oczywiście, rozróżnienie pojęciowe niekoniecznie oznacza, że poszczególnymi pojęciami zostało oddane rzeczywiście istniejące rozczłonkowanie ani że rozdzielnie tych części jest możliwe. Jednak rozwinięcie kryteriów rozróżnienia pojęciowego może przynieść podstawy do zastosowania podziału i, być może także, rozdzielenia prymatu.

\section{Sed contra}

\subsection{Ad primum}

Choć filozoficzne rozważania J. M. Bocheńskiego pomagają wyodrębnić dwa rodzaje autorytetu, to trzeba jasno powiedzieć, że - zdaniem tego dominikańskiego filozofa - najlepszym podmiotem autorytetu jest podmiot, który narzuca swoją wolę podległym sobie przedmiotom autorytetu w sposób mądry. Usiłując to samo zagadnienie przedstawić od strony przedmiotu autorytetu, któremu zostaje narzucona wola, trzeba powiedzieć, że chętniej podporządkowuje się poleceniom wydanym przez podmiot autorytetu, który ma wiedzę odpowiednią do tego, aby określone nakazy sformułować i nadać im treść, która przysłuży się dobru przedmiotu autorytetu $^{31}$.

Zdaniem J. M. Bocheńskiego korzystne jest zespolenie tych dwóch autorytetów w jednym podmiocie, bowiem autorytet deontyczny i autorytet epistemiczny nie tylko nie wykluczają się wzajemnie ${ }^{32}$, lecz także ,jest dobrze, jeśli są obecne razem”33. Autor ten pisze tak: „Powinno być też jasne, że ten sam człowiek w stosunku do tego samego przedmiotu i w tej samej dziedzinie może mieć oba autorytety. Dokładnie mówiąc, chodzi jednak nie o tę samą dziedzinę, ale o dwie dziedziny, ściśle ze sobą związane. Dziedzinę autorytetu deontycznego stanowi w tym przypadku pewna klasa dyrektyw, podczas gdy dziedzinę autorytetu epistemicznego tworzą odpowiadające im zdania praktyczne" ${ }^{34}$. Reguła pragmatyczna sformułowana przez J. M. Bocheńskiego brzmi: „Jest pożądane, aby podmiot autorytetu deon-

\footnotetext{
$3^{\text {3 }}$ Por. J. M. Bocheński, Co to jest autorytet?, dz. cyt., s. 237.

$3^{2}$ Por. tamże.

33 Tamże.

34 Tamże, s. 236.
} 
tycznego był równocześnie podmiotem autorytetu epistemicznego w odpowiedniej dziedzinie" ${ }^{35}$.

Należy więc uznać, że w perspektywie filozoficznej rozdzielenie prymatu nauczania od prymatu jurysdykcji byłoby z punktu widzenia efektywności sprawowania władzy w Kościele szkodliwe. Natomiast trwałe połączenie jest korzystne.

\subsection{Ad secundum}

Reformacja, wbrew temu, co się powszechnie sądzi, nie rozpoczęła się od wystąpienia przeciw papiestwu i kontestowania prymatu ${ }^{36}$. Wydaje się, że ruch ten przyjmował pewną formę władzy nauczania papieża i nawet w pewnych warunkach jego jurysdykcji. Taki pogląd jest implicite zawarty zarówno w dziełach klasyków teologii luterańskiej, jak i we współczesnej refleksji.

Przykładowo M. Luter w Artykułach szmalkaldzkich dopuszcza myśl, że papież może być głową Kościoła. Celem tego może być zgoda i jedność chrześcijan przeciwko sekciarzom i heretykom ${ }^{37}$.

Stanowisko F. Melanchtona określa się jako bardziej pojednawcze wobec katolickiego spojrzenia na prymat niż opinię M. Lutra ${ }^{38}$. Trzeba przypomnieć, że F. Melanchton zgłosił votum separatum do Artykułów szmalkaldzkich i stwierdził, że jeśliby papież „na Ewangelię pozwolił, można by mu z naszej strony przyznać ze względu na pokój i powszechne uspokojenie chrześcijan, którzy już są pod jego władzą i w przyszłości pod jego władzą będą, zwierzchnictwo nad biskupami, jakie już z prawa ludzkiego gdzie indziej ma" ${ }^{39}$.

Obecnie w teologii luterańskiej sprawa papiestwa nie jest dziś określana jako kontrowersyjna. Mówi się o „możliwości urzędu papieskiego, który będzie odnowiony przez Ewangelię, zobowiązany do chrześcijańskiej wolności

35 Tamże, s. 237.

${ }^{6}$ Por. H. Meyer, Primat, dz. cyt., kol. 610-611.

37 Por. Artykuty szmalkaldzkie, cz. II, art. IV, 7.

$3^{8}$ Tak uważa, m.in. M. Hintz, Urząd..., dz. cyt., s. 150; H. Meyer, Primat, dz. cyt., kol. 611.

39 Artykuty szmalkaldzkie, podpisy teologów pod artykułami. Warto zauważyć, że podobne stanowisko zajął Jan Aepjnus z Hamburga: „Jan Aepjnus z Hamburga podpisał, a co do zwierzchności papieskiej, to wraz ze wszystkimi kaznodziejami Hamburga zgadza się ze zdaniem pana Filipa dokonanym na końcu”. 
i będzie obejmował większą część społeczności chrześcijan z luterańskimi Kościołami włącznie" ${ }^{40}$. Takie stanowisko jest konsekwencją opinii luteranów, że choć nauczanie katolickie sformułowanie na Soborze Watykańskim I zdaje się wskazywać na prymat papieża nad Ewangelią, to jednak gdy jest ono dokładnie zinterpretowane, wówczas suwerenność Ewangelii jest w zasadzie zachowana. Sobór Watykański II podporządkowuje już wyraźniej nieomylność papieską nieomylności Kościoła powszechnego ${ }^{41}$.

Widać dość klarownie, że z punktu widzenia luterańskiego możliwe jest istnienie jakiegoś jednego uniwersalnego posługiwania na rzecz jedności Kościoła, które by zawierało nauczanie i rządzenie, jako formy realizacji pryma$\mathrm{tu}^{42}$. „Dlatego też nie wykluczono, iż urząd papieża stanowić mógłby widomy znak jedności Kościołów, przy założeniu, że zostanie on - drogą teologicznej reinterpretacji i praktycznej zmiany swej struktury - podporządkowany prymatowi Ewangelii” ${ }^{3}$.

\subsection{Ad tertium}

Gdy chodzi o teologię katolicką, trzeba powiedzieć, że rozdzielenie prymatu nauczania od prymatu jurysdykcji z punktu widzenia dogmatycznego jest zasadniczo niemożliwe.

Sobór Watykański I naucza, że „ktokolwiek na tej katedrze następuje po Piotrze, ten z ustanowienia samego Chrystusa otrzymuje prymat Piotra w Kościele powszechnym" ${ }^{4}$. W Uwagach na temat Prymatu... Kongregacja Nauki Wiary pisze, że wraz z funkcją nauczycielską prymatu misja następcy św. Piotra obejmuje władzę sprawowania rządów kościelnych poprzez akty jurysdykcji, których celem jest umocnienie lub obrona jedności wiary i komunii ${ }^{45}$. Ta władza jurysdykcji nad wszystkimi Kościołami partykularnymi

40 J. Gryniakow, Problem recepcji wyznania augsburskiego przez katolików, [w:] $Z$ problemów reformacji, t. 3-4, Warszawa 1981-1982, s. 30.

4r Por. tamże, s. 28, 30.

${ }^{42}$ Por. A. Buchenfeld, Prymat Biskupa Rzymu w perspektywie..., dz. cyt., s. 13-14.

43 Raport z Malty, nr 66.

44 „Unde quicumque in hac cathedra Petro succedit, is secundum Christi ipsius institutionem primatum Petri in universam ecclesiam obtinet" (DS 3057).

45 Por. Congregazione per la Dottrina della Fede, Il Primato del Successore di Pietro nel Mistero della Chiesa, 1998, [w:] http://www.vatican.va/roman_curia/congregations/cfaith/ 
wypływa z samej istoty urzędu, a nie jest czymś, co go uzupełnia z motywów ludzkich czy odpowiada na potrzeby historyczne ${ }^{46}$.

Można więc powiedzieć, że papież sprawuje prymat „na różnych płaszczyznach, czuwając nad głoszeniem słowa, nad sprawowaniem sakramentów i liturgii, nad misją, nad dyscypliną i życiem chrześcijańskim" ${ }^{47}$. Te płaszczyzny są ze sobą organicznie i ontologicznie złączone. Ich rozdzielenie jest niemożliwe.

Istniejące pojęciowe rozróżnienie w prymacie jest wtórne wobec zadania, jakie od Chrystusa otrzymał św. Piotr i jego następcy na urzędzie. Swoją misję wykonuje papież, korzystając z prymatu we wszystkich jego aspektach i funkcjach. Prymat musi być pojęty jako jedna najwyższa władza, dana jednej osobie, wypływająca z jednego źródła, czyli z woli Założyciela Kościoła, Jezusa Chrystusa.

Sama idea oddzielenia prymatu jurysdykcji i przyjęcie jako konstytutywnego dla urzędu św. Piotra tylko prymatu nauczania oznacza de facto odrzucenie prymatu papieża. J. Ratzinger pisze, że prymat pozbawiony rangi prawnej to prymat pozbawiony odpowiedzialności, a więc stanowiący zaprzeczenie swojej istoty ${ }^{48}$. Ideę zwykłego prymatu, bez rangi prawnej, jako merytorycznie nieistotną można - zdaniem obecnego papieża - pozostawić poza sferą rozważań ${ }^{49}$.

documents/rc_con_cfaith_doc_19981031_primato-successore-pietro_it.html (23.08.2011); tekst polski: Uwagi Kongregacji Nauki Wiary na temat Prymatu Następcy Piotra w Tajemnicy Kościoła, [dalej: Uwagi na temat Prymatu], nr 10, [w:] http://www.vatican.va/roman_curia/ congregations/cfaith/documents/rc_con_cfaith_doc_19981031_primato-successore-pietro_ pl.html (23.08.2011). Zaliczyć do nich należy przykładowo: zlecenie wyświęcenia nowych biskupów, przyjęcie od nich wyznania wiary katolickiej, dopomaganie wszystkim w wytrwaniu w wyznawanej wierze.

${ }^{46}$ Por. Sacra Congregatio pro Doctrina Fidei, Animadversiones super enuntiatisultimis Commissionis vulgo ARCIC cognominatae, [dalej: Animadversiones], 27 III 1982, Prot. N. 42/76, AAS, 1982, vol. 74, s. 1069-1073; tekst polski: Uwagi o raporcie końcowym „ARCIC I”, dokument dostępny pod adresem: http://www.vatican.va/roman_curia/congregations/cfaith/documents/rc_con_cfaith_doc_19820327_animadversiones_pl.html (23.08.2011), tu: B, III, 2.

47 Ut unum sint, nr 94.

${ }_{48}$ Por. J. Ratzinger, Prymat papieża a jedność Ludu Bożego, [w:] Kościót - Ekumenizm Polityka, Poznań - Warszawa 1990, s. 40.

49 Por. J. Ratzinger, Wyktady bawarskie z lat 1963-2004, przeł. A. Czarnocki, Warszawa 2009, s. 22-23. 


\section{Quanta est nobis via?}

Wyżej przedstawione argumenty oczywiście nie wyczerpują dostępnych możliwości optowania za możliwością rozdziału prymatu lub przeciw niej ${ }^{50}$. Pozwalają one jednak jednoznacznie odpowiedzieć na pytanie: Czy można rozdzielić prymat nauczania od prymatu jurysdykcji? zawarte w tytule referatu - negative. Taki rozdział z punktu widzenia katolickiego jest niemożliwy.

Jedyna droga, jaką można obecnie zaproponować, to dalsze teologiczne poszukiwania, lecz tylko w zakresie, na jaki pozwoli interpretacja dogmatu o prymacie papieskim uchwalona na Soborze Watykańskim I. Badania te mogą iść w kierunku pragnienia realizacji jedności chrześcijaństwa.

Kościół katolicki przecież, zgodnie z wolą Jezusa, kładzie na jedność wielki nacisk, a prymat stanowi wielki dar Chrystusa dla Kościoła, jako niezbędna posługa na rzecz jedności ${ }^{51}$. „Prymat papieski wskazuje na jedność Kościoła i gwarantuje tę jedność. Kolegium Biskupów z papieżem włącznie uwidacznia tę powszechność Kościoła i gwarantuje zachowanie tych różnic w jedności Kościoła, które wypływają ze zróżnicowania między ludźmi i między ludzkimi kulturami" 52 .

Podobnie podochodzą do zagadnienia jedności chrześcijan kościelne Wspólnoty luterańskie ${ }^{53}$. W augsburskim wyznaniu wiary znajduje się sformułowanie odwołujące się do jedności i stawiające jedność jako podstawę na-

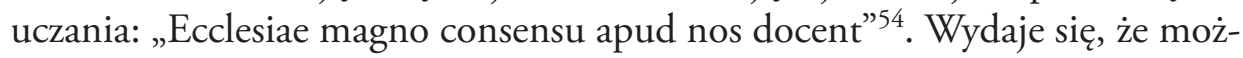
liwość spojrzenia na dyskusyjny obecnie dla luteranów prymat jurysdykcyjny poprzez pryzmat służby papieża na rzecz jedności, pozwoli na przyjęcie przez nich opinii, iż zaakceptowany ekumenicznie urząd następcy św. Piotra będzie służył jedności całego świata chrześcijańskiego ${ }^{55}$.

50 Inne pola argumentacji to np. zagadnienie jedności władzy w Kościele czy kwestia podejścia teologicznego albo pozytywistycznego do prawa kanonicznego.

${ }^{5}$ Por. Uwagi na temat Prymatu, nr 2.

$5^{2}$ A. Zuberbier, Wierzę.. dogmatyka w zarysie, Katowice 1969, s. 216.

53 Nie są one Kościołami w ścisłym sensie, bowiem nie zachowały całkowitej rzeczywistości eucharystycznego misterium. Zob. Congregatio pro Doctrina Fidei, Decl. Dominus Iesus de Iesu Christi atque Ecclesiae unicitate et universalitate salvifica, 6 VIII 2000, AAS, 2000, vol. 92, p. 742-765, tu nr 17.

54 „Zbory nauczają u nas w pełnej zgodności”.

55 Por. J. Ratzinger, Kościót wspólnotą, dz. cyt., s. 31. 
Pełna jedność, jaka zgodnie z wolą Chrystusa, ma istnieć pomiędzy tymi, którzy uważają się za Jego uczniów, wymaga bowiem wspólnego uznania powszechnej posługi kościelnej, „w której wszyscy biskupi czują się zjednoczeni z Chrystusem, a wszyscy wierni znajdą umocnienie swojej wiary" ${ }^{56}$. Kościół katolicki wyznaje, że jest nią posługa prymatu Biskupa Rzymu, następcy św. Piotra. Taka komunia jest bardzo upragniona, lecz może być uzyskana poprzez realizację wezwania, abyśmy wszyscy, jako chrześcijanie, powierzyli się Duchowi Świętemu i Chrystusowi, powierzając się Piotrowi ${ }^{57}$.

\title{
Is it Possible to Separate the Primacy of Jurisdiction from the Primacy of Teaching? Ecumenical Perspective
}

\author{
Summary
}

The problem of papal primacy is one the most fragile issues between Catholics and Protestants. The author of the article discusses the possibility of a separation of the primacy of jurisdiction from the primacy of teaching. The method of reasoning follows the one of St. Thomas: first the arguments pro are given, and later the arguments contra. The arguments are from Catholic theology, Lutheran theology and philosophy. The answer is given from Ecumenical Perspective.

Keywords: primacy, pope, jurisdiction, Magisterium, Church

\footnotetext{
${ }^{5}$ Ut unum sint, nr 97.

57 Por. Uwagi na temat Prymatu, nr 15.
} 